\title{
Calcination thermokinetics of three Brazilian limestones
}

\section{(Termocinética de calcinação de três calcários brasileiros)}

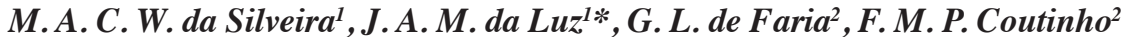 \\ ${ }^{1}$ Federal University of Ouro Preto, School of Mines, Department of Mining Engineering, 35400-000, \\ Ouro Preto, MG, Brazil \\ ${ }^{2}$ Federal University of Ouro Preto, School of Mines, Department of Metallurgical Engineering, \\ Ouro Preto, $M G$, Brazil
}

\begin{abstract}
Limestone and lime producers inadvertently generate a considerable amount of fine material during their processing, consequently becoming a great environmental liability. As far as the industrial calcination process is concerned, there is still a need for an experimental survey on Arrhenius law parameters, as apparent frequency factor and activation energy, referring to Brazilian limestones. The knowledge of these thermokinetic parameters may contribute to energy saving during the industrial calcination process, as well as for allowing the use of limestone fines in other industrial applications. This study aimed to characterize three Brazilian limestones by focusing on their laboratory-scale calcination using both quasi-isothermal and non-isothermal methods to estimate their kinetic parameters. The non-isothermal method (by thermogravimetric analyses) allowed estimating the activation energy for each limestone through the high calcination rate ranges. However, the kinetic parameters estimated by the quasiisothermal method turned out in lower values, indicating the need to control the reactor atmosphere.
\end{abstract}

Keywords: limestone, lime, calcination, thermochemistry, Arrhenius equation.

\section{Resumo}

Os produtores de calcário e cal inadvertidamente geram uma quantidade considerável de material fino durante o processamento, tornando-se um grande passivo ambiental. Quanto ao processo de calcinação, a indústria ressente-se de dados experimentais da lei de Arrhenius, como fator de frequência aparente e energia de ativação, referentes aos calcários brasileiros. $O$ conhecimento desses parâmetros termocinéticos pode diminuir o consumo energético durante o processo de calcinação industrial, além de permitir o uso de finos de calcário em outras aplicações industriais. Este trabalho teve como objetivo caracterizar três calcários brasileiros, concentrando-se em sua calcinação em escala laboratorial, usando método quase isotérmico e dinâmico (termogravimétrico) para estimar seus parâmetros cinéticos. O método dinâmico permitiu estimar a energia de ativação de cada calcário através das regiões de alta taxa de calcinação. Porém, os parâmetros cinéticos estimados pelo método quase isotérmico resultaram em valores mais baixos, indicando a necessidade de controlar a atmosfera do reator.

Palavras-chave: calcário, cal, calcinação, termoquímica, equação de Arrhenius.

\section{INTRODUCTION}

Calcination of carbonate rocks is largely influenced by industrial operating conditions and its lithotype, especially limestone and dolomite for production of calcium oxide $(\mathrm{CaO})$ and a mixture of calcium oxide and magnesium oxide $(\mathrm{MgO})$, known respectively as lime and dolomitic lime. This industrial process usually requires strict control of contaminating components such as silica, alumina, and iron oxides present in carbonate rock, which directly interfere in the final quality of the product. As a result, usually, it is necessary a complex processing circuit that involves grinding and concentration processes such as flotation, magnetic

*jaurelio@ufop.edu.br

Dhttps://orcid.org/0000-0002-7952-2439 separation, among others, inevitably producing fines (even below $45 \mu \mathrm{m}$ ) within the current technological context [1]. Although the current industrial processes meet the market requirements for the final product purity, the progressive increasing requirement for a higher purity (usually requiring grinding to finer sizes, in order to achieve a higher degree of liberation) has led to a tendency towards the accumulation of large amounts of fine material, which at a first moment does not have a direct industrial application, becoming a potential environmental liability. Driven by this reason, recent studies $[2,3]$ dedicated to the technical feasibility of limestone fines agglomeration as an alternative route for the use of this material in the agricultural, metallurgical, and calcination industries have resulted very often products outside market specifications used rather restrictively.

Calcitic limestone $\left(\mathrm{CaCO}_{3}\right)$, lime $(\mathrm{CaO})$, calcium hydroxide $\left[\mathrm{Ca}(\mathrm{OH})_{2}\right]$, and dolomite $\left[\mathrm{CaMg}\left(\mathrm{CO}_{3}\right)_{2}\right]$ are 
used in the ironwork and steelwork industry in lowering of melting temperature (as flux or liquefying additive), and also for removal of impurities present in the ore and/or concentrates (as a slagging additive). These impurities are constitutionally linked to acid oxides (in particular $\mathrm{SiO}_{2}$ and $\mathrm{Al}_{2} \mathrm{O}_{3}$ ) and spontaneously react, under the thermochemical conditions inside the reactor, with the basic components (conventionally also expressed as basic oxides, such as $\mathrm{CaO}$ and $\mathrm{MgO}$ ) from the calcined carbonates. In addition, the size and porosity of limestone particles applied in the iron ore agglomeration processes have a favorable influence on the reducibility and mechanical strength of the iron ore sinter $[4,5]$. As far as the blast furnace-based ironmaking process is concerned, since it is a packed bed operation, there is a pressure drop to be counteracted by the combustion and reduction gas percolating across the entire furnace load. The Ergun equation describes the gas pressure drop in the bed (compact or fluidized) as a function of the equipment, the environment reduction, and especially the particle size and shape of the material $[6,7]$, as can be seen in Eq. A:

$$
\frac{\Delta \mathrm{p}}{\mathrm{L}}=150 \frac{(1-\varepsilon)^{2}}{\varepsilon^{3}} \frac{\eta_{\mathrm{f}}}{\left(\Psi . \mathrm{d}_{\mathrm{p}}\right)^{2}} \frac{\mathrm{Q}_{\mathrm{vf}}}{\mathrm{A}}+1.75 \frac{1-\varepsilon}{\varepsilon^{3}} \frac{\rho_{\mathrm{f}}}{\Psi . \mathrm{d}_{\mathrm{p}}}\left(\frac{\mathrm{Q}_{\mathrm{vf}}}{\mathrm{A}}\right)^{2}
$$

where $\Delta \mathrm{p}$ is the gas pressure drop $[\mathrm{Pa}]$, A the reactor crosssectional area $\left[\mathrm{m}^{2}\right], \psi$ the mean Wadell sphericity of particles $[-], \eta_{\mathrm{f}}$ the dynamic viscosity coefficient of the fluid [Pa.s], $\varepsilon$ the particulate bed porosity (static or fluidized) [-], L the particulate bed thickness $[\mathrm{m}], \mathrm{d}_{\mathrm{p}}$ the effective particle diameter $[\mathrm{m}], \mathrm{Q}_{\mathrm{vf}}$ the volumetric fluid flow rate through the bed $\left[\mathrm{m}^{3} / \mathrm{s}\right]$, and $\varrho_{\mathrm{f}}$ the fluid density $\left[\mathrm{kg} / \mathrm{m}^{3}\right]$.

The preceding equation highlights the great influence exerted by parameters such as the (harmonic) mean particle size, particle sphericity, as well as the open porosity of the bed. For a given fixed thickness (height) of the particulate bed, the dynamic head losses caused by the reduction of gas flow are smaller for more spheroidal and coarser particles accordingly to their higher permeability (resulting from their higher open porosity). Additionally, fines entrainment in upward gas flow greatly limits the fine particle use in the blast furnaces because of the consequent bed fouling or pore-blocking. In addition, using limestone fines could make the metallurgical process inefficient, since their endothermic calcination is a naturally reversible process. In other words, its product (quicklime) is usually an unstable compound, theoretically, for temperatures below the temperature of dissociation of the carbonates in the limestone, which typically ranges between 1053 and $1643 \mathrm{~K}$ $[8,9]$. Temperatures below this range make a positive Gibbs free energy variation ( $\Delta \mathrm{G}$, expressed in $\mathrm{kJ} / \mathrm{mol})$, according to Eqs. $\mathrm{B}$ and $\mathrm{C}$, where $\Delta \mathrm{G}^{\circ}$ is the standard Gibbs free energy change $[\mathrm{kJ} / \mathrm{mol}], \Delta \mathrm{H}^{\circ}$ is the standard enthalpy change $[\mathrm{kJ} / \mathrm{mol}]$, and $\Delta S^{\circ}$ is the standard entropy change $[\mathrm{kJ} / \mathrm{mol} . \mathrm{K}]$. Naturally, the spontaneity of the direct reaction only occurs when $\Delta \mathrm{G}$ is negative when the temperature is greater than the one of dissociation of the carbonate in the limestone, for a standard thermochemical condition. If $\Delta \mathrm{G}$ is zero, the reaction is at equilibrium (it is noteworthy $\Delta \mathrm{G}$ is gotten from the actual thermochemical condition and from $\Delta \mathrm{G}^{\circ}$ through the Nernst equation).

$$
\begin{aligned}
& \mathrm{CaCO}_{3(\mathrm{~s})} \leftrightarrow \mathrm{CaO}_{(\mathrm{s})}+\mathrm{CO}_{2(\mathrm{~g})} \uparrow \\
& \Delta \mathrm{G}^{\mathrm{o}}=\Delta \mathrm{H}^{\mathrm{o}}-\mathrm{T} . \Delta \mathrm{S}^{\mathrm{o}}
\end{aligned}
$$

The thermodynamic and kinetic aspects of the calcination are not as simple at first sight, as one might be led to believe from the Eqs. B and C. Parameters such as enthalpy of reaction, kinetic constants of the Arrhenius law (Eq. $\mathrm{D})$, frequency factor (A), and exponential parameter, or activation energy $\left(\mathrm{E}_{\mathrm{a}}\right)$ depend, in fact, on the constitution of the carbonate and the operating conditions [9]. There is still a lack of experimental survey of such parameters referring to the Brazilian limestones, marbles, and dolomites.

$$
\mathrm{k}=\mathrm{A} \cdot \mathrm{e}^{-\mathrm{E}_{\mathrm{a}} / \mathrm{R} \cdot \mathrm{T}}
$$

where $\mathrm{R}$ is the gas constant and $\mathrm{T}$ the temperature. As the Arrhenius equation is concerned with heterogeneous reactions, $\mathrm{E}_{\mathrm{a}}$ is actually an apparent activation energy. But it is common in the literature to deal with this parameter as the canonical Arrhenius activation energy also for heterogeneous reactions, although the original Arrhenius' derivation assumes a homogeneous reaction (gas-gas). Furthermore, analogous extrapolation of the so-called frequency factor (A), the Arrhenius' pre-exponential parameter, is more prone to criticism. Anyway, this approach allows a comparative effect (including with the data from literature) if the reactions were really first order $(n=1)$ over the entire temperature range studied. In light of this reasoning, the most judicious study of the evolution of $n$ with temperature was kept beyond the scope of this article and will be the aim of future publication. Therefore, there is still a scientific and technological knowledge gap in order to fully understand the thermodynamic and kinetic aspects of calcination and its relationship with the typology of limestones employed in industrial operation.

The aim of this study was to characterize the physical and thermochemical aspects of three Brazilian limestones technologically, in order to firstly highlight the effect of operational conditions (reactor atmosphere, temperature and time) on the calcination of these limestone fines, as a function of their effective specific surface area (which is a function of particle size distribution, porosity, and permeability), and secondly to estimate the kinetic parameters of each type of limestone. The knowledge of thermokinetic properties of these limestones may contribute to avoid energy losses during the industrial calcination process as well as to allow the use of limestone fines in other industrial applications.

\section{MATERIALS AND METHODS}

Materials: three representative samples of Brazilian limestones from different typologies, with a mean particle size above $100 \mu \mathrm{m}$ and total weight around $150 \mathrm{~kg}$, were collected at different quarries from distinct regions of Brazil. 
A sample of calcitic limestone from the Bambuí group quarry at the central-western region in the State of Minas Gerais, a sample of dolomite marble from the deactivated Cumbe quarry in the Ouro Preto municipality, in Minas Gerais, and a sample of dolomitic limestone from the Construtora Sucesso's quarry, at Barro Duro Municipality in Piauí State, northeast of Brazil. The samples were collected from each quarry product stockpile following a random selection process of the particles in order to ensure their representativeness and homogeneity (nevertheless the Gy's fundamental error is inherently associated with particulate system sampling).

Methods: firstly, all the three samples were submitted to a sequential comminution process: hand breaking with a crack hammer followed by jaw crushing until the top size reached $8 \mathrm{~mm}$. Then, all three samples were submitted to wet sieving. The particle size distributions of the three samples were well described by truncated Rosin-Rammler-SperlingBennett distribution (with top size, $\mathrm{x}_{\max }$ ), as expressed by Eq. $\mathrm{E}$, and shown in Table I and Fig. 1. As a result of wet sieving, the size range between 2.38 and $1.00 \mathrm{~mm}$ was selected for the technological characterization and calcination tests for all three samples (Fig. 2). The regression parameters were estimated using a non-linear algorithm from the EasyPlot software package [10]. This algorithm used a MarquardtLevenberg filter (which, unlike the descending simplex search algorithm, allowed to estimate the uncertainty associated with the regression values).

$$
\mathrm{Y}=\mathrm{p}\left(0 \leq \mathrm{x} \leq \mathrm{X}<\mathrm{x}_{\max }\right)=1-\exp \left[\ln \frac{1}{2} \cdot\left(\frac{\frac{\mathrm{x}}{\mathrm{X}_{\max }-\mathrm{X}}}{\frac{\mathrm{X}_{50}}{\mathrm{X}_{\max }-\mathrm{X}_{50}}}\right)^{\mathrm{n}}\right]
$$

The characterization included the determinations of bulk and true densities, from triplicate measurements using a glass pycnometer with water, a helium Ultrapycnometer 1000 , flowability, and Hausner index [11]. Specific surface area, porosity, and pore size were measured by the BET nitrogen adsorption technique at $77 \mathrm{~K}$. The chemical analysis was performed by combining gravimetry, to measure the silica $\left(\mathrm{SiO}_{2}\right)$ content, and inductively coupled plasma-optical emission spectrometry (Agilent, 725 ICP-OES). The minerals were detected by X-ray diffraction (XRD) technique (using Rietveld refinement), and microstructural morphology was analyzed by using a table-top sized Phenom scanning electron microscope coupled with energy-dispersive X-ray spectrometer (SEM/EDS) equipped with backscattered (BSE)

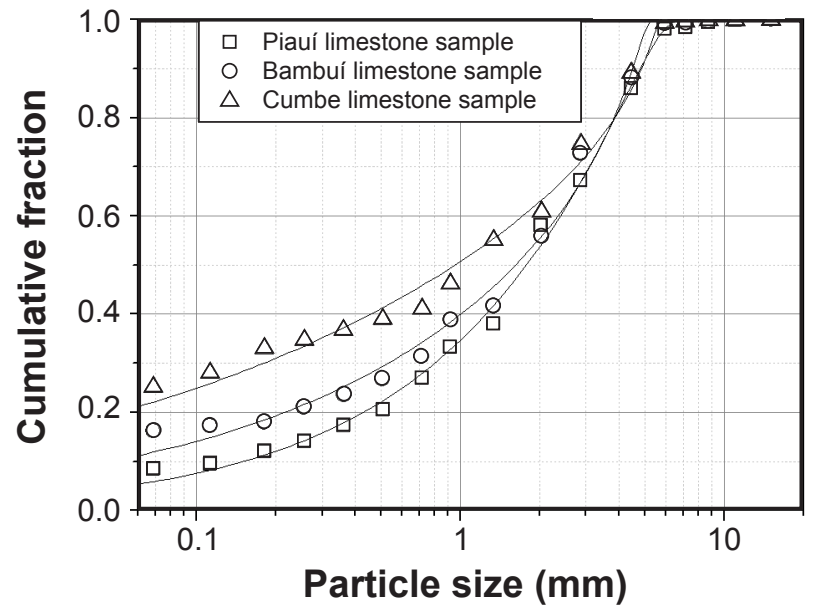

Figure 1: Particle size distribution curves of limestone samples prepared for the technological characterization and the calcination tests.

[Figura 1: Distribuições granulométricas das amostras de calcário preparadas para caracterização tecnológica e testes de calcinação.]

and secondary (SE) electrons detectors, which generated a grayscale image of the sample at high magnifications (80 to $100000 \mathrm{X}$ ). Also, thermogravimetric essays of powdered limestone samples (below $45 \mu \mathrm{m}$ ) were conducted in a thermogravimetric analyzer (TA Instr., TGA Q50) with $\mathrm{N}_{2}$ flow to provide an inert atmosphere. The thermogram obtained was a basis for kinetic parameters determination through this dynamic method at a constant heating rate of $0.167 \mathrm{~K} / \mathrm{s}$.

Calcination experiments were conducted in electric muffle furnaces with temperature rate control by a microprocessor as a quasi-isothermal method. For this campaign, samples (weighing about $50 \mathrm{~g}$ and sizing between 2.38 and 1.00 $\mathrm{mm}$ ) were placed in the preheated muffle furnace with non-controlled atmosphere and the calcination time and temperature parameters were set up for all limestone samples, as follows: i) calcination times of $900 \mathrm{~s}(0.25 \mathrm{~h}), 1800 \mathrm{~s}(0.50$ h), $2700 \mathrm{~s}(0.75 \mathrm{~h})$, and $3600 \mathrm{~s}(1.00 \mathrm{~h})$; and ii) calcination temperatures of 1048.1, 1123.1, 1198.1, 1273.1, 1348.1, and $1423.1 \mathrm{~K}$. Data evaluation from calcination tests were performed according to the method adopted in [9]. It was assumed that calcination in the adopted temperature range is an irreversible reaction, unimolecular, and a first-order process, i.e., the decomposition rate of $\mathrm{CaCO}_{3}$ would be approximately linear.

Table I - Parameters of Rosin-Rammler-Sperling-Bennett distribution for crushed samples.

[Tabela I - Parâmetros da distribuição de Rosin-Rammler-Sperling-Bennett para as amostras fragmentadas.]

\begin{tabular}{ccccc}
\hline Limestone sample & $\begin{array}{c}\text { Median size, } \\
\mathrm{x}_{50}(\mathrm{~mm})\end{array}$ & $\begin{array}{c}\text { Modulus or } \\
\text { sharpness index, } \mathrm{n}\end{array}$ & $\begin{array}{c}\text { Theoretical top size, } \\
\mathrm{x}_{\max }(\mathrm{mm})\end{array}$ & $\begin{array}{c}\text { Pearson's coefficient } \\
\text { of determination, } \mathrm{R}^{2}\end{array}$ \\
\hline Piauí & 1.788 & 0.6912 & 7.501 & 0.9970 \\
Bambuí & 1.628 & 0.4841 & 5.356 & 0.9896 \\
Cumbe & 0.959 & 0.3639 & 5.755 & 0.9888 \\
\hline
\end{tabular}




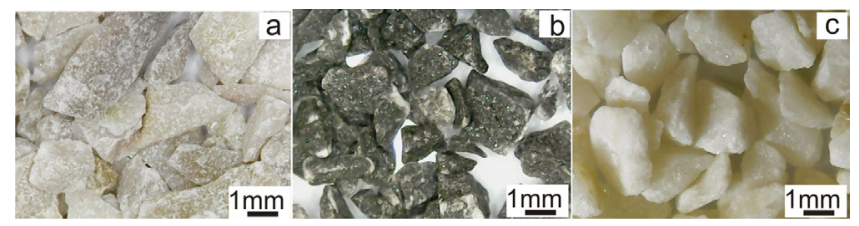

Figure 2: Images showing the particle shape of the studied limestone samples: a) Piauí; b) Bambuí; and c) Cumbe.

[Figura 2: Imagens mostrando a forma das partículas das amostras de calcário: a) Piauí; b) Bambuí; e c) Cumbe.]

\section{RESULTS AND DISCUSSION}

\section{Technological characterization}

Table II presents the results of bulk density, true density (or actual specific mass) determined with water and gas, as well as the Hausner index and flowability for all studied samples. One can see that the Piauí limestone had a bulk density lower than that of the Bambuí limestone, although presenting a higher true density. This was attributed to more anisometric particles, which caused a greater number of voids between the particles (open pores). In turn, Table III presents the surface area, porosity, and mode pore diameter obtained by the BET adsorption technique. The mode pore diameter was determined by non-local density functional theory, which is the most robust in flaw/pore size characterization [12]. It can be clearly noticed the specific surface area of the Bambuí limestone sample was greater than those values of the other two samples, implying correspondingly to higher porosity. This fact naturally pointed toward a greater amount of surface area available to react during calcination. At first glance, this feature leads one to believe that the calcination rate of the Bambuí limestone probably should be higher than the other two limestone samples, because $\mathrm{CO}_{2}$ diffusion is claimed to be directly proportional to the pore diameter $[13,14]$, which in turn is affected by the type of limestone.

As the multi-elemental chemical analyses are concerned, Table IV shows that both Piauí and Cumbe limestone samples were dolomitic limestones, due to their amount of $\mathrm{CaO}$ and $\mathrm{MgO}$, while in contrast, Bambuí limestone was a calcitic limestone, as a result of the high $\mathrm{CaO}$ content and the very low $\mathrm{MgO}$ content [15]. One also can see the presence of major impurities, such as $\mathrm{SiO}_{2}, \mathrm{Al}_{2} \mathrm{O}_{3}$, and $\mathrm{Fe}_{2} \mathrm{O}_{3}$, mainly in the
Piauí and Cumbe limestone samples, justifying the obtained low surface area values in Table III, as mentioned in another study [16]. Table V shows the mineralogical analysis by XRD using the Rietveld refinement. The following mineral phases were detected: dolomite and quartz in the Piauí and Cumbe limestone samples; and calcite and quartz in the Bambuí limestone sample, as already pointed out by the chemical analysis. It is worth mentioning that the presence of a magnesium mica, i.e., phengite, $\mathrm{K}(\mathrm{Al}, \mathrm{Mg})_{2}(\mathrm{OH})_{2}(\mathrm{Si}, \mathrm{Al})_{4} \mathrm{O}_{10}$, in the Cumbe limestone sample, was also detected, which could be eventually a detrimental factor to the calcination reaction kinetics of this limestone.

Fig. 3 displays SEM/EDS micrographs of limestone samples from Piauí, Bambuí, and Cumbe. Fig. 3a shows that the Piauí limestone presented dolomite grains with welldefined cleavage planes creating some intergranular porosity due to the great variation of orientation in the contact between particles, as can be seen in detail in Fig. 3b. By the way, the small hairy prisms grown on the well-formed carbonate faces are rare acicular goethite crystals. In turn, Figs. $3 \mathrm{c}$ and $3 \mathrm{~d}$ show Bambuí limestone and highlight the overwhelming presence of calcite grains, having a wide variation of size, which causes greater compactness and, consequently, a lower intergranular porosity. Finally, in Figs. 3e and 3f, it can be seen that Cumbe limestone presented coarser and rounder grains, compared to the other two samples, showing that this lithotype underwent partial recrystallization (due to regional metamorphism), becoming almost marble.

Thermogravimetric analysis was conducted aiming at identifying temperature ranges with a high calcination rate, i.e., where a more significant weight decrease occurred (because calcination is a gas-solid system, with solid thermal decomposition, resulting in an evolving gaseous product). Fig. 4a shows the weight decrease results for limestone samples, under the heating rate of $0.167 \mathrm{~K} / \mathrm{s}$, and the final temperature close to $1273 \mathrm{~K}$. Decomposition began at approximately $900 \mathrm{~K}$ for the Bambuí and Cumbe limestone samples, and $850 \mathrm{~K}$ for the Piauí limestone sample. It is important to note that, since calcination is a hydrate and carbonate decomposition reaction, these temperature differences were probably associated with the amount of chemically bound entities such as hydroxyl, water, and carbonate, which were eliminated $\left(\mathrm{as}_{2} \mathrm{H}_{2} \mathrm{O}\right.$ and $\mathrm{CO}_{2}$ ) during calcination through the pores of the limestone. These quantities varied according to the microstructure and

Table II - Bulk density, true density, and flowability for limestone samples.

[Tabela II - Densidade aparente, densidade real e escoabilidade das amostras de calcário.]

\begin{tabular}{cccccc}
\hline Limestone sample & $\begin{array}{c}\text { Bulk } \\
\text { density } \\
\left(\mathrm{kg} / \mathrm{m}^{3}\right)\end{array}$ & $\begin{array}{c}\text { True density by } \\
\text { water pycnometry } \\
\left(\mathrm{kg} / \mathrm{m}^{3}\right)\end{array}$ & $\begin{array}{c}\text { True density } \\
\text { by helium } \\
\text { pycnometry } \\
\left(\mathrm{kg} / \mathrm{m}^{3}\right)\end{array}$ & $\begin{array}{c}\text { Hausner } \\
\text { index, HI }\end{array}$ & Flowability \\
\hline Piauí & 1315 & $2813 \pm 32$ & $2868 \pm 1$ & 1.18 & Easy \\
Bambuí & 1381 & $2652 \pm 40$ & $2757 \pm 2$ & 1.11 & Easy \\
Cumbe & 1448 & $2845 \pm 11$ & $2892 \pm 3$ & 1.13 & Easy \\
\hline
\end{tabular}


Table III - Surface area and intrinsic porosity obtained by the BET technique for the limestone samples.

[Tabela III - Área superficial e porosidade intrínseca obtidas pela técnica BET das amostras de calcário.]

\begin{tabular}{cccc}
\hline $\begin{array}{c}\text { Limestone } \\
\text { sample }\end{array}$ & $\begin{array}{c}\text { Specific } \\
\text { surface area } \\
\left(\mathrm{m}^{2} / \mathrm{kg}\right)\end{array}$ & $\begin{array}{c}\text { Porosity } \\
(\%)\end{array}$ & $\begin{array}{c}\text { Mode pore } \\
\text { diameter } \\
(\mathrm{m})\end{array}$ \\
\hline Piauí & 222.5 & 0.0886 & $2.90 \times 10^{-9}$ \\
Bambuí & 345.3 & 0.1473 & $2.65 \times 10^{-9}$ \\
Cumbe & 265.6 & 0.1081 & $1.93 \times 10^{-9}$ \\
\hline
\end{tabular}

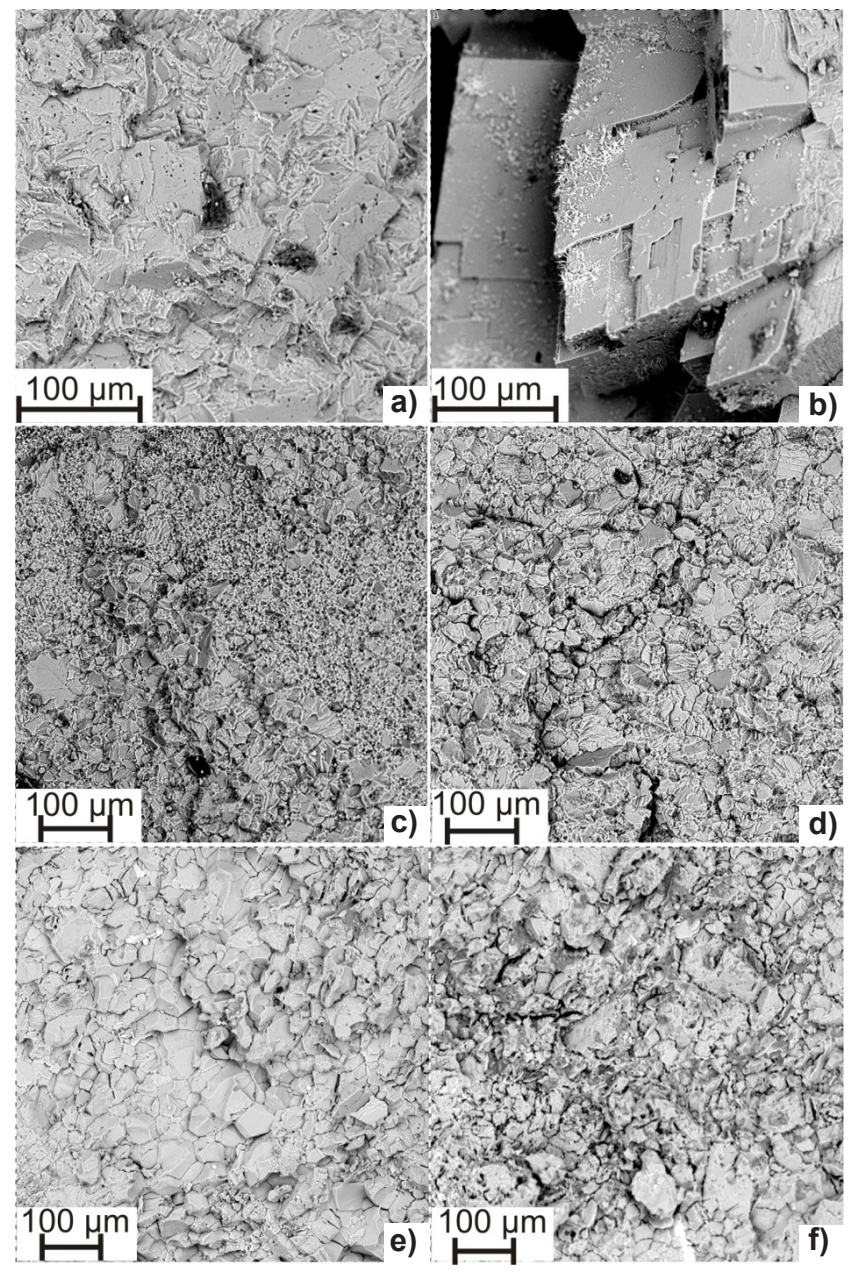

Figure 3: SEM micrographs of the limestone samples: a,b) Piauí; c,d) Bambuí; and e,f) Cumbe.

[Figura 3: Micrografias de MEV das amostras de calcário: a,b) Piauí; c,d) Bambuí; e e,f) Cumbe.]
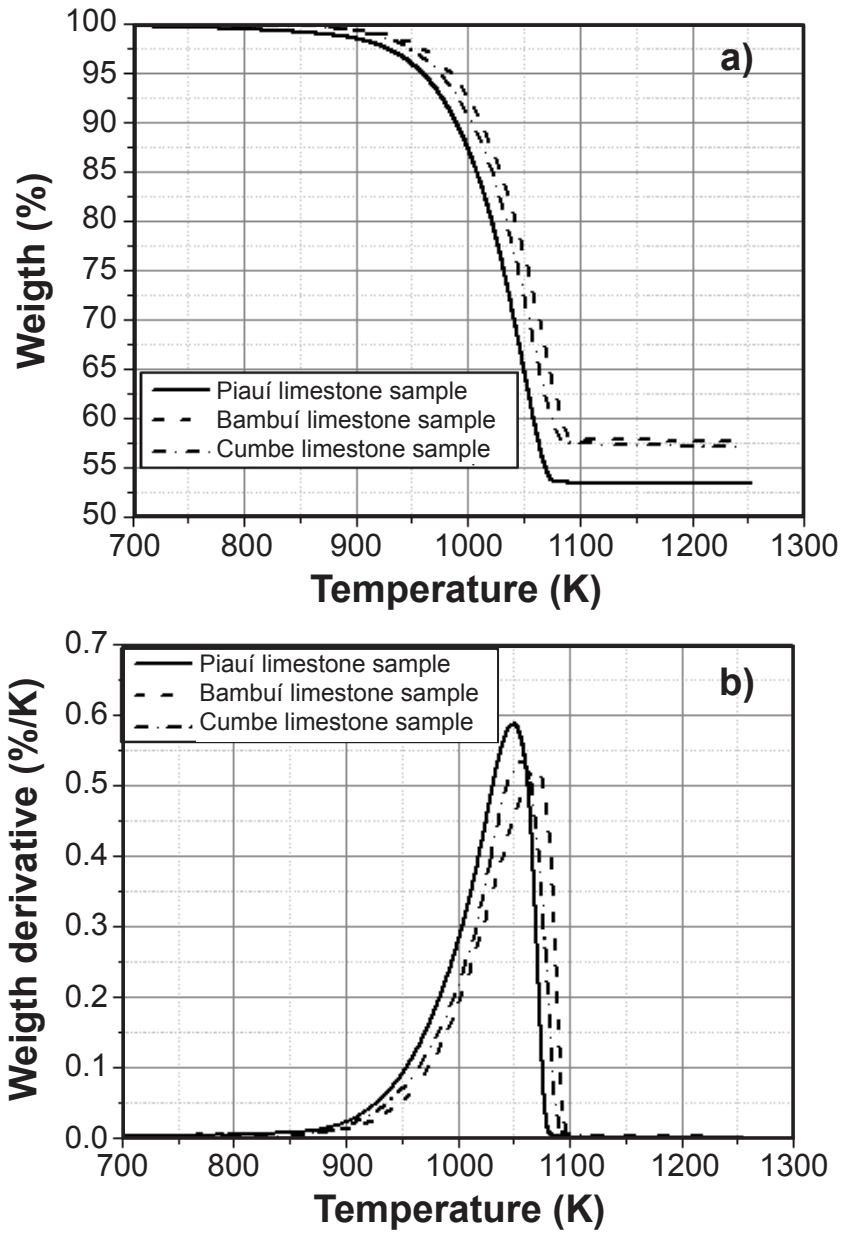

Figure 4: Thermograms (dynamic method with a heating rate of $0.167 \mathrm{~K} / \mathrm{s}$ ) for the three limestone samples (a) and corresponding limestone decomposition rates as a temperature function (b).

[Figura 4: Termogramas (método dinâmico com taxa de aquecimento de 0,167 K/s) para as três amostras de calcário (a) e as correspondentes taxas de calcinação dos calcários em função da temperatura $(b)$.

Table V - Mineralogical composition by XRD with the Rietveld method for the limestone samples (\%).

[Tabela V - Composição mineralógica por DRX com o método de Rietveld das amostras de calcário (\%).]

\begin{tabular}{ccccc}
\hline Sample & Calcite & Dolomite & Quartz & Phengite \\
\hline Piauí & - & 98.9 & 1.1 & - \\
Bambuí & 99.0 & - & 1.0 & - \\
Cumbe & - & 92.8 & 2.9 & 4.3 \\
\hline
\end{tabular}

Table IV - Chemical composition by ICP-OES of the samples (expressed as oxide content, weight \%).

[Tabela IV - Composição química por ICP-OES das amostras (expresso como teor de óxido, \% em massa).]

\begin{tabular}{ccccccccccccccc}
\hline Sample & $\mathrm{CaO}$ & $\mathrm{MgO}$ & $\mathrm{SiO}_{2}$ & $\mathrm{Fe}_{2} \mathrm{O}_{3}$ & $\mathrm{Al}_{2} \mathrm{O}_{3}$ & $\mathrm{Na}_{2} \mathrm{O}$ & $\mathrm{K}_{2} \mathrm{O}$ & $\mathrm{SO}_{3}$ & $\mathrm{P}_{2} \mathrm{O}_{5}$ & $\mathrm{TiO}_{2}$ & $\mathrm{SrO}$ & $\mathrm{MnO}$ & $\mathrm{LOI}$ & $\mathrm{MIO}$ \\
\hline Piauí & 27.07 & 19.49 & 6.17 & 1.11 & 0.18 & 0.04 & 0.05 & 0.03 & 0.07 & 0.01 & 0.01 & 0.09 & 45.64 & 7.46 \\
Bambuí & 53.36 & 0.88 & 2.16 & 0.65 & 0.51 & 0.10 & 0.14 & 0.04 & 0.06 & 0.02 & 0.09 & 0.03 & 42.14 & 3.31 \\
Cumbe & 25.25 & 18.60 & 10.04 & 1.05 & 1.87 & 0.02 & 0.83 & $<0.01$ & 0.12 & 0.08 & $<0.01$ & 0.17 & 42.22 & 12.97 \\
\hline
\end{tabular}

*LOI: loss on ignition; MIO: major impurity oxides $\left(\mathrm{SiO}_{2}+\mathrm{Fe}_{2} \mathrm{O}_{3}+\mathrm{Al}_{2} \mathrm{O}_{3}\right)$. 
the provenance of each limestone. Since the diffusion of these volatile products is a monotonically increasing function of pore diameter, it was expected that there were such differences between the samples. Therefore, as can be seen in Table IV, limestones with lower amounts of major impurity oxides (MIO) provided a greater decomposition (weight loss), which can also be related to the value of loss on ignition (LOI) [16]. Fig. 4b highlights the highest decomposition rate for the limestone samples through their weight loss derivatives. It is possible to observe that Piauí limestone presented a weight decrease peak close to $1050 \mathrm{~K}$. In contrast, the Bambuí and Cumbe limestone samples showed their weight decrease peaks at temperatures close to 1070 and $1060 \mathrm{~K}$, respectively.

a)

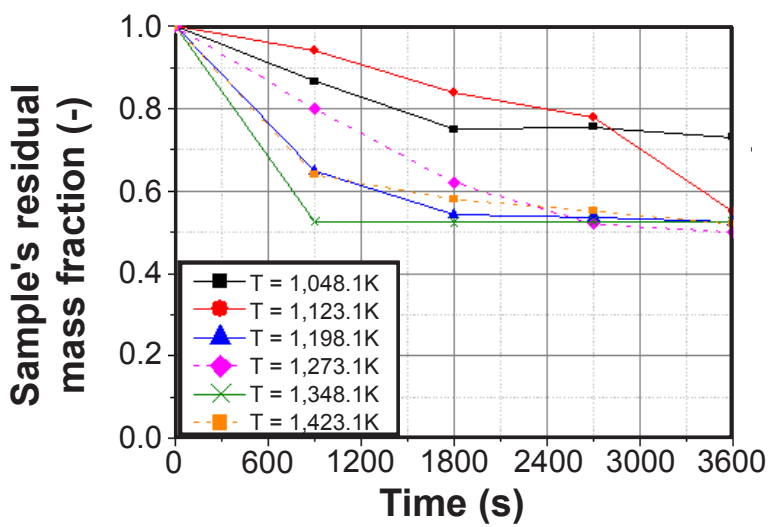

b)

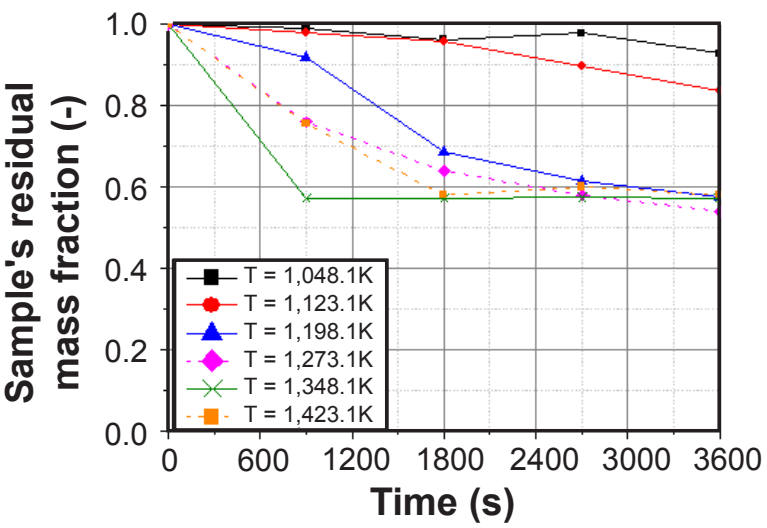

c)

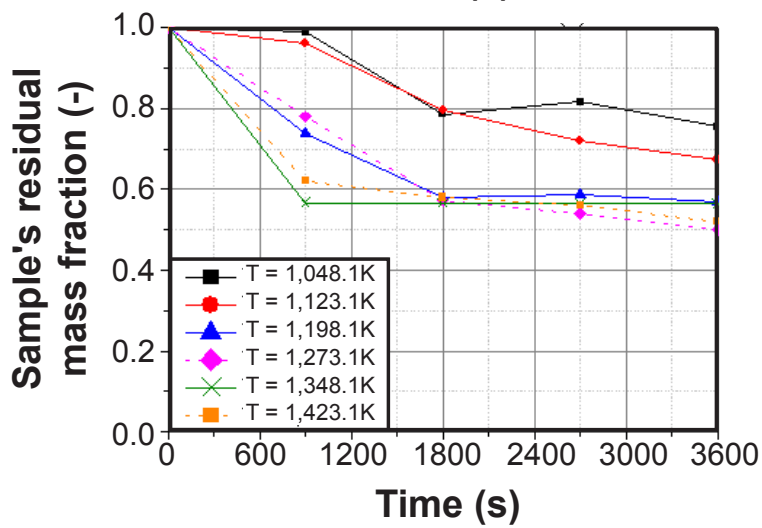

These values of temperature agree with another study [16] in which it is affirmed that calcination of limestone for quicklime production begins at 1053.1 K. It was also noted that Piauí and Cumbe limestone samples had no subsequent mass variation at temperatures higher than $1080.1 \mathrm{~K}$, evidencing that all the material had already been calcined. Similarly, this behavior occurred with the Bambuí limestone sample, but at temperatures higher than $1100.1 \mathrm{~K}$.

\section{Calcination experiments}

Calcination experiments using the isothermal method are summarized in Figs. 5a to 5c, which display the thermal
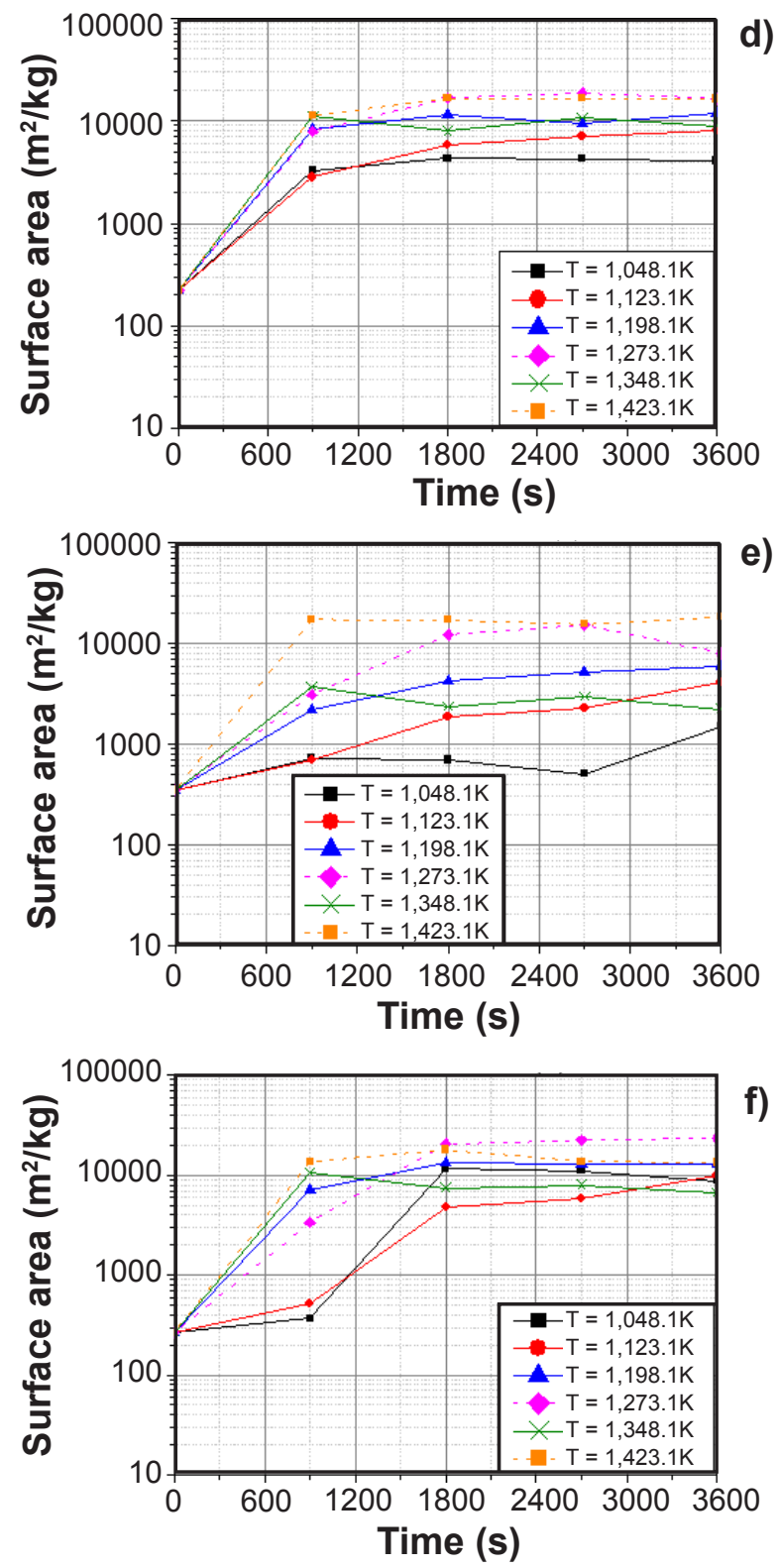

Figure 5: Temperature effect on quasi-isothermal decomposition (a-c) and surface area (d-f) of limestone samples: a,d) Piauí; b,e) Bambuí; and $\mathrm{c}, \mathrm{f})$ Cumbe.

[Figura 5: Efeito da temperatura na decomposição quase isotérmica (a-c) e na área superficial (d-f) das amostras de calcário: a,d) Piauí; b,e) Bambuí; and c,f) Cumbe.] 


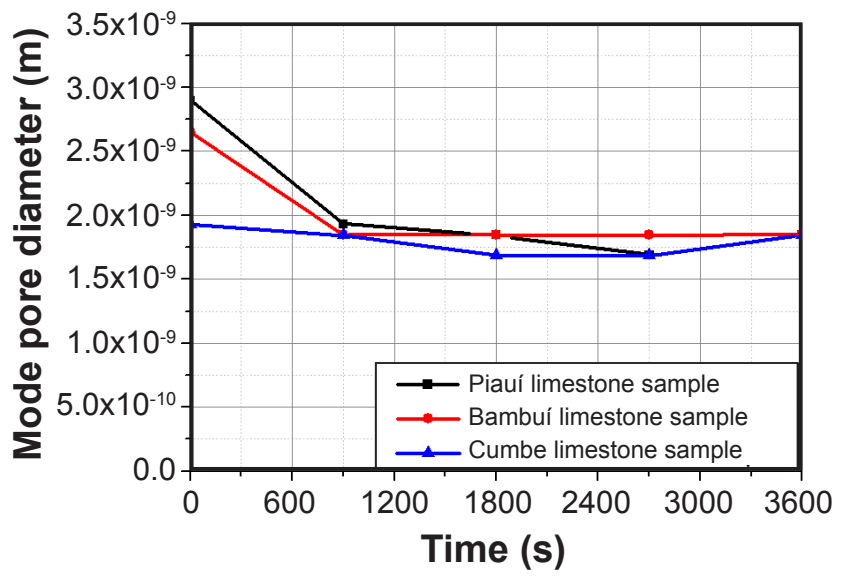

Figure 6: Mode pore diameter evolution of the layer of $\mathrm{CaO}$ formed for all limestone samples at $1423.1 \mathrm{~K}$.

[Figura 6: Evolução da moda do diâmetro dos poros da camada de CaO formada para todas as amostras a 1423,1 K.]

decomposition curves for the limestone samples at different temperatures and intervals of time. These figures show the time decaying rates for the residual mass fraction of samples have decelerated as temperatures rose, for the three limestones. At 1048.1 and $1123.1 \mathrm{~K}$, the decomposition rate was the slowest, compared to the other temperatures, as expected. However, at these same temperatures, there was a trend for increasing decomposition rate as the reaction proceeded. For the other four higher test temperatures, namely $1198.1,1273.1,1348.1$, and $1423.1 \mathrm{~K}$, the first 15 min of reaction were characterized by higher decomposition rates. However, as time goes on, these rates decreased, characterizing a damping effect, i.e., a slowing reaction rate. It was also observed that after 30 min all samples had, unexpectedly, a higher mass loss at $1273.1 \mathrm{~K}$, compared to the higher temperature tests, at 1348.1 and $1423.1 \mathrm{~K}$. This curious behavior may be associated with a possible difficulty where $\mathrm{CO}_{2}$ evolved out from limestone particles, since diffusion is known to increase monotonically with respect to pore diameter $[13,14]$. Thus, as verified by several researchers [17-20], at $1423.1 \mathrm{~K}$ the growth rate for the specific surface area of the limestone particles during calcination decreased by sintering, simultaneously with pore occlusion in the layer of lime formed, making carbon dioxide molecules more difficult to percolate out of the limestone particles. As a matter of fact, Figs. $5 \mathrm{~d}$ to $5 \mathrm{f}$ display this phenomenon underlying the evolution of the specific surface area of each sample under calcination, and Fig. 6 shows this pore occlusion phenomenon in the layer of lime formed caused by sintering at $1423.1 \mathrm{~K}$.

Another important issue to consider is the one already studied in the literature [21, 22]. It was found a grain size decrease, which caused the calcination rate to rise, leading to the acceleration of carbonate decomposition for finer particles (in the 0.4 to $2.0 \mathrm{~mm}$ range when compared to the coarser range of 15 to $50 \mathrm{~mm}$ ). This may explain the initial rapid conversion of the particles with sizes between 2.38 and $1.00 \mathrm{~mm}$ tested in this study after the first $15 \mathrm{~min}$; the remaining time also caused some particle agglomeration, and consequently, the pore shrinkage inside the already formed lime layer. Fig. 7 shows the calcined limestone particles after the first $15 \mathrm{~min}$ at $1423.1 \mathrm{~K}$ for all the three lithotypes.

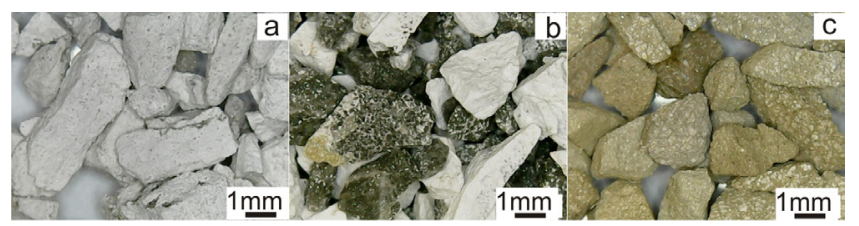

Figure 7: Images of calcined particles during $15 \mathrm{~min}$ from the limestone samples at 1423.1 K: a) Piauí; b) Bambuí; and c) Cumbe. [Figura 7: Imagens de partículas das amostras de calcário calcinadas por 15 min a 1423,1 K: a) Piauí; b) Bambuí; e c) Cumbe.]

\section{Calculation of kinetic parameters}

Experimental data of calcination using the quasiisothermal method conducted in electric muffle furnaces initially allowed calculating the reaction rate constant $(\mathrm{k})$ of each test in terms of fractional conversion of carbonate into lime $\left(\mathrm{X}_{\mathrm{c}}\right)$ by Eq. F. The decomposition reaction was considered approximately a first-order irreversible reaction [9]. Currently, many researchers $[9,16]$ still calculate in an old-fashioned way the reaction rate constant $(\mathrm{k})$ through linear regressions. As there are many non-linear regression software available, such as EasyPlot, which allows for a more complex mathematical analysis, $\mathrm{k}$ was easily determined by a plot of $1-X_{c}$ versus $t$, which provided an exponential decay function, for each temperature condition in the calcination tests. By having the values of rate constants (k), its dependence on temperature was determined for each temperature condition (Table VI) by the Arrhenius equation (Eq. D) similar to the procedure adopted in literature [9]. Plots in Fig. 8 illustrate the dependence of reaction rate on temperature for the Piauí, Bambuí, and Cumbe limestone samples. From the relationship between reaction rate and the temperature, it was possible to determine the kinetic parameters, apparent activation energy $\left(E_{a}\right)$, and frequency factor (A) from Eq. D, for each sample, as shown in Table VII.

$$
1-X_{c}=e^{-k t}
$$

Another approach for the determination of kinetic parameters was proposed through thermogravimetric data, where its principle is based on the weight variation as a function of decomposition kinetics [23]. As the thermogravimetry applied in this study was performed as a dynamic method (i.e., the temperature increased linearly, according to a steady heating rate of $0.167 \mathrm{~K} / \mathrm{s}$ ), it was possible to estimate the kinetic parameters of thermal decomposition through the thermogram. There are many proposals for obtaining kinetic parameters by means of thermogravimetry [24]. In all cases, the decomposition rates follow this generalized equation: 
Table VI - Temperature effect on reaction rate constant $(\mathrm{k})$ for the limestone samples.

[Tabela VI - Efeito da temperatura na constante da taxa de calcinação (k) para as amostras de calcário.]

\begin{tabular}{cccc}
\hline $\begin{array}{c}\text { Temperature } \\
(\mathrm{K})\end{array}$ & \multicolumn{3}{c}{ Reaction rate constant, $\left.\mathrm{k}^{-1} \mathrm{~s}^{-1}\right)$} \\
\hline 1048.1 & $104 \times 10^{-6}$ & $17 \times 10^{-6}$ & $82 \times 10^{-6}$ \\
1123.1 & $131 \times 10^{-6}$ & $42 \times 10^{-6}$ & $113 \times 10^{-6}$ \\
1198.1 & $225 \times 10^{-6}$ & $167 \times 10^{-6}$ & $194 \times 10^{-6}$ \\
1273.1 & $219 \times 10^{-6}$ & $195 \times 10^{-6}$ & $222 \times 10^{-6}$ \\
1348.1 & $238 \times 10^{-6}$ & $207 \times 10^{-6}$ & $211 \times 10^{-6}$ \\
1423.1 & $220 \times 10^{-6}$ & $188 \times 10^{-6}$ & $219 \times 10^{-6}$ \\
\hline
\end{tabular}

$-d w / d t=A \cdot \exp \left(-E_{a} / R \cdot T\right) \cdot w^{n}$

where $\mathrm{w}$ is the residual fraction of the sample mass after time $\mathrm{t}, \mathrm{n}$ is the actual reaction order, $\mathrm{A}$ is the pre-exponential parameter, or apparent frequency factor, $\mathrm{E}_{\mathrm{a}}$ is the exponential parameter or apparent activation energy, $\mathrm{R}$ is the constant of an ideal gas, and $\mathrm{T}$ is temperature. It is necessary to emphasize that because it is a dynamic method, the kinetic parameters $\mathrm{E}_{\mathrm{a}}$ and $\mathrm{A}$ do not have strictly the same physical meaning as the parameters obtained by the Arrhenius approximation in an isothermal method, i.e., the kinetic parameters by the dynamic method is apparent, since they do not report the same values obtained by the quasi-isothermal method. The unity model [23] was adopted in order to obtain the kinetic parameters from the thermogravimetric data, since the model assumes that the mass loss rate of the sample is dependent only on the constant rate, the sample mass (w) and temperature. And, as a consequence, this model assumes a first-order reaction, making use of the Arrhenius model with no extra information needed. In this regard, it should be noted that some researchers [25] also found calcination of another carbonate, magnesite $\left(\mathrm{MgCO}_{3}\right)$, as a first-order reaction through thermogravimetric analysis. Assuming that the reaction was first order $(n=1)$, firstly the Eq. G was linearized (rather by historical reason) to obtain the following Eq. H:

$$
\ln \left(\frac{\mathrm{dw}}{\mathrm{dt}} \frac{1}{\mathrm{w}}\right)=\ln \mathrm{A}-\frac{\mathrm{E}_{\mathrm{a}}}{\mathrm{R} \cdot \mathrm{T}}
$$

Therefore, from a constructed graph $\ln [(\mathrm{dw} / \mathrm{dt}) .(1 / \mathrm{w})]$ versus $1 / \mathrm{T}$, the apparent frequency factor (A) and apparent activation energy $\left(E_{a}\right)$ were obtained through the linear and angular coefficients of the adjusted line, respectively. Table VIII presents the estimated kinetic parameters of each sample studied from thermogravimetric data. According to several researchers [26-28], the activation energy for limestone calcination generally ranges from 92.2 to 209.5 $\mathrm{kJ} / \mathrm{mol}$ and depends on the limestone chemical composition and on operational conditions. Besides that, other researchers [29] state decreasing particle size leads to a decrease in the activation energy, whereas it increases with the sample
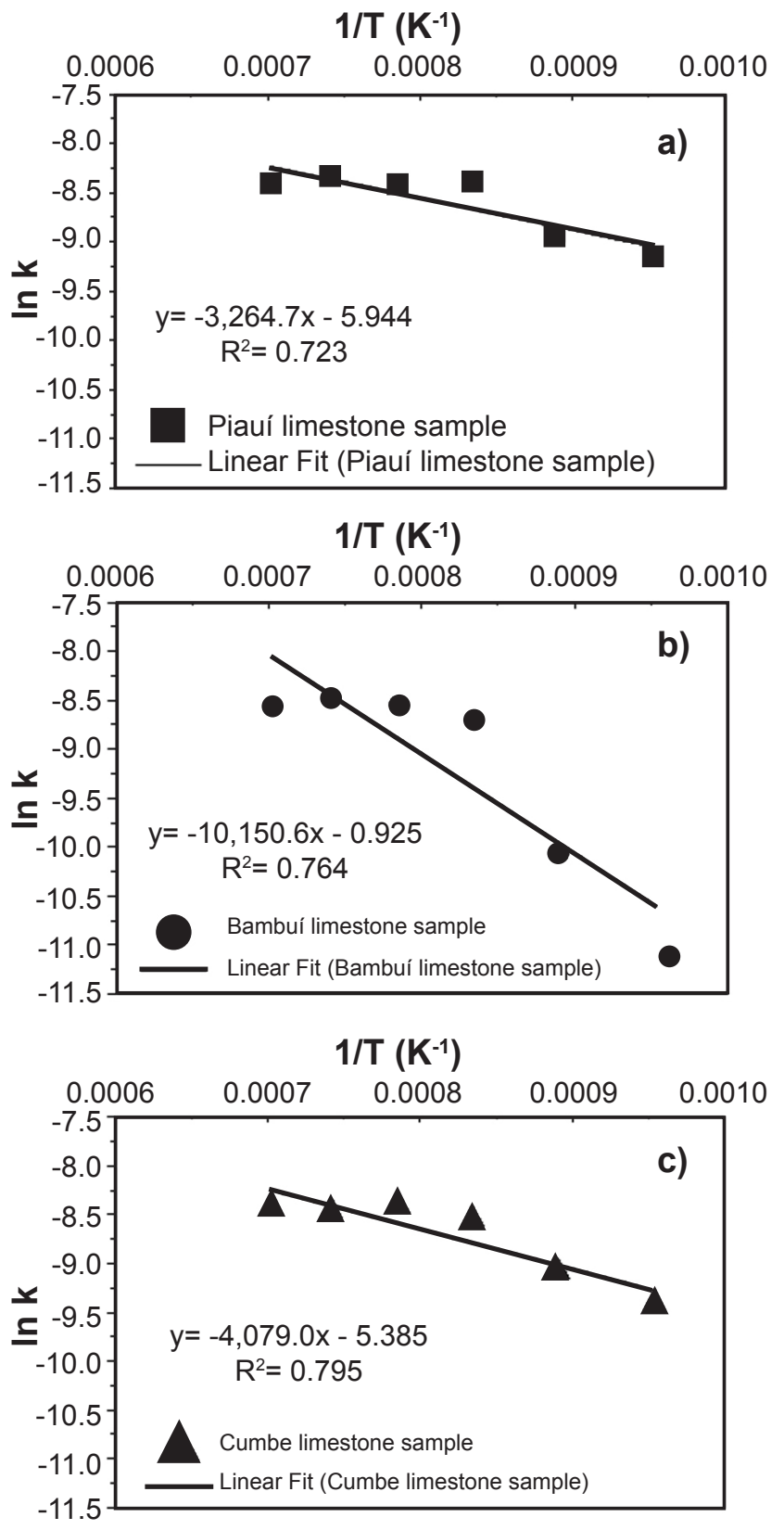

Figure 8: Reaction rate dependence on temperature of limestone samples.

[Figura 8: Dependência da taxa de calcinação com a temperatura das amostras de calcário.]

weight or bulk density. It is also important to point out the presence of $\mathrm{Al}_{2} \mathrm{O}_{3}$ and $\mathrm{SiO}_{2}$ may increase the activation energy for calcination, while the presence of $\mathrm{MgCO}_{3}$ lowers its value [30]. Therefore, the activation energy values obtained from thermogravimetric data seems satisfactory because they were kept within the above-mentioned range.

By observing the kinetic parameters obtained from the isothermal method (Table VII) carried out accordingly with an example from the literature [9], and those obtained through the thermogravimetric data (Table VIII), it was verified that there was a relative difference of the activation energy and a dramatic increase of the frequency factor. These 
Table VII - Activation energy and frequency factor for limestone samples from the quasi-isothermal method.

[Tabela VII - Energia de ativação e fator de frequência para as amostras de calcário pelo método quase isotérmico.]

\begin{tabular}{ccc}
\hline $\begin{array}{c}\text { Limestone } \\
\text { sample }\end{array}$ & $\begin{array}{c}\text { Activation energy } \\
(\mathrm{kJ} / \mathrm{mol})\end{array}$ & $\begin{array}{c}\text { Frequency factor } \\
\left(\mathrm{s}^{-1}\right)\end{array}$ \\
\hline Piauí & 26.9 & 389.9 \\
Bambuí & 84.4 & 2.5 \\
Cumbe & 33.9 & 218.1 \\
\hline
\end{tabular}

differences may be explained by the fact that the calcination tests were conducted with an isothermal method with a noncontrolled atmosphere, i.e., probably with high $\mathrm{CO}_{2}$ partial pressure, which may have lowered the calcination rate, as can be seen in Eq. I [21], and consequently decreased the activation energy.

$$
(\mathrm{r})_{\mathrm{c}}=\mathrm{K}_{\mathrm{c}} \cdot \mathrm{S}_{\mathrm{e}}(1-\theta)\left(1-\frac{\mathrm{P}_{\mathrm{CO}_{2}}}{\mathrm{P}_{\text {eq }}}\right)
$$

where $(\mathrm{r})_{\mathrm{c}}$ is the reaction rate of calcination $\left[\mathrm{kmol} /\left(\mathrm{m}^{3} . \mathrm{s}\right)\right]$, $\mathrm{k}_{\mathrm{c}}$ the chemical reaction rate constant $\left[\mathrm{kmol} /\left(\mathrm{m}^{2} . \mathrm{s}\right)\right], \mathrm{S}_{\mathrm{e}}$ the specific surface area $\left[\mathrm{m}^{2} / \mathrm{m}^{3}\right], \theta$ the fraction of active sites occupied by $\mathrm{CO}_{2}[-], \mathrm{P}_{\mathrm{CO}}$ the $\mathrm{CO}_{2}$ partial pressure $[\mathrm{Pa}]$, and $\mathrm{P}_{\mathrm{eq}}$ the equilibrium $\mathrm{CO}_{2}$ partial pressure [Pa]. Another important issue is that the parameters obtained by thermogravimetry are, in fact, apparent parameters because they are provided by a continuum heating system as this technique uses a constant heating rate. Knowing that the frequency factor (A) multiplies the exponential term of the Arrhenius equation (Eq. D), its value clearly contributes to the value of the rate constant $(\mathrm{k})$. In addition, the exponential part of Eq. $\mathrm{D}$ expresses the fraction of reactant molecules that have enough kinetic energy to react, as governed by the MaxwellBoltzmann law. This fraction can run from zero to near unity, depending on the magnitude and the temperature [31].

Some researchers [32] have verified the kinetic rates of $\mathrm{CaCO}_{3}$ decomposition depend on the BET surface area of the limestone particles, which yields consistent activation energy and pre-exponential factor when using a dependency on $\mathrm{CO}_{2}$, as proposed elsewhere [33]. In other words, these low values of the kinetic parameters obtained by the quasiisothermal method were probably due to the decrease of the

Table VIII - Apparent activation energy and frequency factor estimated from thermogravimetric data.

[Tabela VIII - Energia de ativação e fator de frequência aparentes estimados pelos dados termogravimétricos.]

\begin{tabular}{ccc}
\hline $\begin{array}{c}\text { Limestone } \\
\text { sample }\end{array}$ & $\begin{array}{c}\text { Apparent activation } \\
\text { energy }(\mathrm{kJ} / \mathrm{mol})\end{array}$ & $\begin{array}{c}\text { Apparent frequency } \\
\text { factor }\left(\mathrm{s}^{-1}\right)\end{array}$ \\
\hline Piauí & 181.6 & 1633115.3 \\
Bambuí & 193.6 & 4355717.9 \\
Cumbe & 190.5 & 3605604.5 \\
\hline
\end{tabular}

available surface area during the reaction evolution caused by sintering and the consequent pore occlusion in the layer of $\mathrm{CaO}$ formed. The higher difference in the frequency factor parameter (A) occurs probably due to the fraction of molecules (amount of available surface area) that can react when the activation energy is zero, or if the kinetic energy of all the molecules is exceeded, which is an unusual fact, although there is evidence of unhindered (unconstrained) reactions. In this manner, the thermal decomposition reaction of these Brazilian limestones had a heavy dependence on operational conditions (mainly the reactor atmosphere and temperature) and specific surface area available, i.e., a function of their particle size, porosity, and permeability. From this observation and considering Eq. $\mathrm{J}$ of a simple power balance [34], it was possible to suggest that the knowledge of these factors and kinetic parameters may contribute to the reduction of the cost and energy loss of the calcination process of these limestones for any industrial applications.

$$
\sum \mathrm{Q}_{\text {net }}+\sum \mathrm{W}_{\text {net }}+\sum \dot{\mathrm{n}}_{\text {in }} \cdot \mathrm{h}_{\text {in }}+\sum \dot{\mathrm{n}}_{\text {out }} \cdot \mathrm{h}_{\text {out }}=0
$$

where $\mathrm{Q}$ is the heat rate required or released [W], $\mathrm{W}$ the work rate required or produced through the boundary [W], $\dot{n}$ the molar flow rate required $[\mathrm{mol} / \mathrm{s}]$, and $\mathrm{h}$ the specific enthalpy of each compound $[\mathrm{J} / \mathrm{mol}]$. Subscripts in and out refer to streams at system inlet and outlet, respectively.

\section{CONCLUSIONS}

The technological characterization showed the influence of the crushed particle shape when comparing bulk density, true density, porosity, and specific surface area. Moreover, by obtaining the Hausner index, it was determined that the three limestones had an easy flowability. The results of the chemical analysis allowed classifying the limestone samples in dolomitic or calcitic according to the concentrations of $\mathrm{MgO}$ and $\mathrm{CaO}$, as well as the observation of impurities present, which caused a decrease of the surface area and the calcination rate of the material. SEM analysis of the samples shed light on the porosity and surface area values acquired by instrumental characterization. Despite the fact that the thermogravimetric analysis is a non-isothermal method, the high calcination rate regions allowed for the estimation of the apparent activation energy for each limestone sample, which remained within the literature range. On the other hand, the kinetic parameters obtained by the quasi-isothermal method with a non-controlled atmosphere turned out in lower values of the activation energy compared with literature, indicating the need to control the reactor atmosphere during calcination tests. Finally, it was possible to verify the influence of the reactor atmosphere, temperature, porosity, and specific surface area on the calcination rate for these Brazilian limestones. The knowledge of these latter factors and the Arrhenius parameters for these limestones (even though, strictly speaking, they are apparent counterparts of those canonical thermochemical properties) may contribute to 
decrease energy consumption and to improve performances in any of their industrial applications. Regarding blast furnace operation, some agglomeration processes would additionally have to be evaluated to allow the use of limestone fines. Nevertheless, on the other hand, for their use in ceramics, fines are desired since raw-material comminution is usually a real necessity for further processing.

\section{ACKNOWLEDGMENTS}

The authors are grateful to the Brazilian Council for the Technological and Scientific Development (CNPq), Foundation for Research Support of the State of Minas Gerais (FAPEMIG), and the Brazilian Federal Agency for Support and Evaluation of Graduate Education (CAPES) for their financial support of this work. The authors would like to take the opportunity to thank the following laboratories at the School of Mines at the Federal University of Ouro Preto: Laboratory of Environmental Geochemistry, Laboratory of Interface Phenomena of the Department of Mine Engineering, Laboratory of Thermal Treatments and Optical Microscopy in the Department of Metallurgical Engineering. The authors would also like to thank Construtora Sucesso S.A. for sending us samples from its limestone quarry in Piauí State, Brazil.

\section{REFERENCES}

[1] J.A. Sampaio, S.L.M. Almeida, in "Rochas \& minerais industriais, usos e especificações", $2^{\mathrm{a}}$ ed., A.B. da Luz, F.A.F. Lins (Ed.), CETEM/MCT, Rio Janeiro (2008) 363.

[2] E.A.S. Garcia, A.C. Silva, E.M.S. Silva, M.R. Barros, in XXVI Enc. Nac. Tratam. Minér. Metal. Extrat. (2015) 59.

[3] A.C. Silva, E.M.S. Silva, M.R.D. Barros, D.Y. Marinho, Tecnol. Metal. Mater. Miner. 13, 4 (2016) 365.

[4] T. Umadevi, U.K. Bandopadhyay, P.C. Mahapatra, M. Prabhu, M. Ranjan, Steel Res. Int. 81, 6 (2010) 419.

[5] M. Iljana, A. Kemppainen, T. Paananen, O. Mattila, E. Pisilä, M. Kondrakov, T. Fabritius, Int. J. Miner. Process. 141 (2015) 34.

[6] N. Hidaka, J. Iyama, T. Matsumoto, K. Kusakabe, S. Morooka, Powder Technol. 95, 3 (1998) 265.

[7] F.O. Milhomem, J.A.M. Luz, in Proc. XIII ${ }^{\text {th }}$ Int. Miner. Process. Symp., Bodrum (2012).

[8] KirkOthmer Encyclop. Chem. Technol., $4^{\text {th }}$ ed., John Wiley Sons 15 (2001) 552.

[9] K. Mu'azu, M. Abdullahi, A.S. Akuso, Nig. J. Basic
Appl. Sci. 19, 1 (2011) 116.

[10] S. Karon, "Easy Plot: scientific graphing and data analysis", Spiral Software (2002).

[11] F.O. Milhomem, J.A.M. Luz, Holos 3 (2016) 32.

[12] R.M.M.L. Carrott, A.J.E. Candeias, P.J.M. Carrott, P.I.

Ravikovitch, A.V. Neimark, A.D. Sequeira, Microporous Mesoporous Mater. 47 (2001) 323.

[13] P.C. Okonkwo, S.S. Adefila, Int. J. Eng. Sci. Technol. 4, 2 (2012) 391.

[14] C. Cheng, E. Specht, Thermochim. Acta 449, 1-2 (2006) 8.

[15] J.J. Pettijohn, Rocas sedimentarias, $3^{\text {rd }}$ ed., Edigraf, Buenos Aires (1976) 419.

[16] A.M.M. Soltan, M.A. Serry, Adv. Appl. Ceram. 110, 7 (2011) 409.

[17] M. Alonso, J.M. Cordero, B. Arias, J.C. Abanades, Chem. Eng. Technol. 37, 1 (2014) 15.

[18] K. Feng, S.J. Lombardo, J. Ceram. Process. Res. 3, 3/1 (2002) 101.

[19] A. Trikkel, R. Kuusik, Oil Shale 20, 4 (2003) 491.

[20] Y. Liu, Y. Yang, J. Power Energy Eng. 3, 4 (2015) 56.

[21] F. García-Labiano, A. Abad, L.F. De Diego, P. Gayán, J. Adánez, Chem. Eng. Sci. 57, 13 (2002) 2381.

[22] B.D. Soares, C.E. Hori, C.E. Batista, H.M. Henrique, Mater. Sci. Forum 591 (2008) 352.

[23] A.N. Pereira, O.V. Trevisan, J. Braz. Soc. Mech. Sci. Eng. 36, 2 (2014) 393.

[24] A. Jerez, E. Ramos, M. Gaitán, M.L. Veiga, C. Pico, Thermochim. Acta 115 (1987) 175.

[25] F. Demir, B. Dönmez, H. Okur, F. Sevim, Chem. Eng. Res. Des. 81, 6 (2003) 618.

[26] I. Ar, G. Doğu, Chem. Eng. J. 83, 2 (2001) 131.

[27] M. Fahad, Y. Iqbal, Int. J. Thermophys. 35, 2 (2014) 361.

[28] J. Adanez, F. García-Labiano, V. Fierro, Chem. Eng. Sci. 55, 18 (2000) 3665.

[29] F. Acke, I. Panas, Thermochim. Acta 303, 2 (1997) 151.

[30] P. Gupta, A. De, C. Biswas, J. Eng. Res. 5, 1 (2017).

[31] G. Del Mundo, K. Moussa, P. Chacha, F.-D. Odufalu, G. Mudda, Kan, C.F. Kelvin, "Arrhenius equation”, Chemistry LibreTexts, https://chem.libretexts.org/ (2017).

[32] J.R. Fernandez, S. Turrado, J.C. Abanades, React. Chem. Eng. 4, 12 (2019) 2129.

[33] J.M. Valverde, P.E. Sanchez-Jimenez, L.A. PérezMaqueda, J. Phys. Chem. C 119, 4 (2015) 1623.

[34] M. Al-Breiki, Y. Bicer, SN Appl. Sci. 1, 10 (2019) 1272. (Rec. 15/12/2019, Rev. 27/01/2020, 20/03/2020, Ac. $23 / 03 / 2020)$ 